\title{
A Comparative Analysis of Adjustment of Nigerian Selected Macro Economic Variables to Deregulated Exchange Rate System
}

\author{
Ifeoma Chinelo Amakor \\ Department of Banking and Finance, Nnamdi Azikiwe University, Awka \\ E-mail: ic.amakor@unizik.edu.ng
}

Onyinye Eneh

Department of Accountancy, Nnamdi Azikiwe University, Awka

E-mail: o.eneh@gmail.com

Received: December 13, 2018 Accepted: June 25, 2019 Published: June 27, 2019

doi:10.5296/jpmr.v5i1.14984ＵRL: https://doi.org/10.5296/jpmr.v5i1.14984

\begin{abstract}
This study is a comparative analysis of how Nigerian macro economic variables of Balance of Payment and Real Sector performance (surrogated by Real Gross Domestic Product) reacted to exchange rate deregulation in Nigeria. One of the reasons why countries deregulate their exchange rate is to avail themselves the benefits of international trade, and the international trade transaction of every nation is depicted in its balance of payment position. In order to ascertain the significance of Naira deregulated exchange rate on the selected variables, a pre and post deregulation analyses were carried out using Paired Sample T Test staring from 1960 to 1985 as pre deregulation period and 1986 to 2011 as post deregulation period. The result revealed that both Balance of Payment and Real Sector Performance reacted significantly to exchange rate deregulation. While the influence of deregulation of exchange rate on Balance of Payment was negative, it showed a positive influence on Real Sector performance. The researchers concluded that deregulation of exchange rate did not increase the Nigerian general export, but oil export only, which is also an indication that Nigerian domestic industries did not contribute significantly to the country's export level. We recommend that the monetary authority can consider placing a crawling peg on Naira exchange rate level in order to regulate the level of currency depreciation; this will reduce the cost of production for the domestic industries as most of their raw materials are imported.
\end{abstract}


Again the export ability of the Nigerian domestic industries can be enhanced by granting them export incentives such as free international packaging and external credit guarantee.

Keywords: exchange rate deregulation, real sector performance, balance of payment

\section{Introduction}

Before the introduction of the structural adjustment program in 1986, Nigeria practiced a fixed or regulated exchange rate system. Fixed exchange rate system is a system where the rate at which the domestic currency is exchange for other currencies is determined or controlled by the monetary authority. During that period, Naira had more value than US Dollar and British Pound Starlings. In 1986, Naira was said to be overvalued, and the regulatory authorities were told to deregulate the exchange rate in order to ascertain the real value of Naira and also facilitate the exportation of other products like rubber, cocoa, palm oil, tin, groundnut etc, which constitute the county's major export products before the discovering of oil. Despite the market determined exchange rate system adopted by the Nigerian monetary authority, the Nigerian economy has witnessed instability and continuous depreciation of naira value in foreign exchange market, massive importation of finished goods with adverse consequence on domestic production, balance of payment disequilibrium, depletion in nations external reserve level, declines in the standard of living of the populace and increased cost of production which also leads to cost push inflation (Aliyu, 2011).

Could it be argued that the floating or deregulated exchange rate system being practiced in Nigeria has brought all these distortion in the economy? Or could it be linked to other economic factors. This has also been a major point of argument among academics. Some scholars like Orji, Ogbuabor \& Okeke (2018), Isibor, Olokoyo, Arogundade, Osuma \& Ndigwe (2019), Aliyu (2011), Asher (2012), and Obansa, Okoroafor, Aluko and Millicent (2013), are of the opinion that deregulated or fluctuating exchange rage have positively influenced developing economies like Nigeria, while other scholars like Tams-Alasia, Okoye \& Ejemegovwi (2018), David, Umeh and Ameh (2010), Eichengreen and Leblang (2003), Servén (2003), Arize, Osang, and Slottje (2000), and Eme and Johson (2012) strongly believed that deregulated exchange rate effects developing economies negatively. In view of this, this work seeks to carry out a pre and post deregulation analysis on some selected macro economic variables such as Balance of Payment and Real Sector performance proxied by Real Gross Domestic Product (RGDP) from 1960 to 1985 and 1986 to 2011, ie 25 years before and 25 year after deregulation in Nigeria.

The broad objective of the study is to evaluate the impact of exchange rate deregulation on Nigerian economy, while the specific objectives of the study were; to examine the relationship between deregulated exchange rate and balance of payment in Nigeria and to ascertain the relationship between deregulated exchange rate and the real sector performance in Nigeria. The researcher hypotheses that; deregulated exchange rate has no significant relationship with Nigerian Balance of Payment and deregulated exchange rate has not significantly influence Nigerian Real sector productivity. 


\subsection{The Conceptual Review}

Exchange rate system can be seen as the way in which the monetary authority manages its currency in relation to other foreign currencies. Before deciding on the type of exchange rate system a country will adopt, the monetary authorities have to consider some factors like; the stage of the economic development, the balance of payment position, monetary and fiscal policy and the prevailing economic situation. The exchange rate systems include; floating exchange rate, fixed exchange rate and pegged float exchange rate (Auboin \& Ruta, 2011).

According to Lumen boundless-economics, a floating exchange rate or fluctuating exchange rate which is also known as deregulated exchange rate is a type of exchange rate regime where the value of currency in relation to others is allowed to freely fluctuate subject to market forces. A currency that uses a floating exchange rate is known as a floating currency.

Many economists believe that floating exchange rates are the best possible exchange rate regime because it automatically adjusts to economic circumstances. However, floating exchange rate increases foreign exchange volatility in developing countries; this is because developing economies often have the majority of their liabilities denominated in other currencies instead of the local currency. While businesses and banks in these economies earn their revenue on local currency but have to convert it to another currency to pay their debts, so depreciation of the local currency's value will put the entire economy's financial sector in danger, though a fully floating currency system is hardly obtainable (Ibenta, 2014).

A fixed exchange-rate system (also known as pegged exchange rate system) is a currency system in which governments try to maintain their currency value constant against a specific currency or good. It is also a system where a currency's value is tied to the value of another single currency, to a basket of other currencies, or to another measure of value, such as gold. In a fixed exchange-rate system, a country's government decides the worth of its currency in terms of either a fixed weight of an asset, another currency, or a basket of other currencies. To ensure that a currency will maintain its "pegged" value, the country's central bank maintains reserves of foreign currencies and gold. They can sell these reserves in order to intervene in the foreign exchange market to make up excess demand or take up excess supply of the country's currency. So the central bank of a country remains committed at all times by buying and selling its currency at a fixed price. This is one reason why governments maintain reserves of foreign currencies. If the exchange rate drifts too far below the desired rate, the government buys its own currency in the market using its reserves. This places greater demand on the market and pushes up the price of the currency. If the exchange rate drifts too far above the desired rate, the government sells its own currency, thus increasing its foreign reserves. Another, method of maintaining a fixed exchange rate is by simply making it illegal to trade currency at any other rate. This method is rarely used because it is difficult to enforce and often leads to a black market in foreign currency.

Pegged floating exchange rate systems are when a currency is pegged to some band or values, either fixed or periodically adjusted. These are a hybrid of fixed and floating exchange system. Or it can be seen as an exchange rate system that fixes an exchange rate around a certain value, but still allows fluctuations, usually within certain values, to occur. Pegged 
float regimes can be inform of crawling bands, crawling pegs and horizontal band pegs (Lumen boundless-economics).

According to Adebayo (2013), real sector comprises of households, nonfinancial organizations and Non-Profit Institutions and serving households, involved in the production and distribution of goods and service necessary to meet the consumption demand of an economy. The key output sectors that make up the real sector are the primary sector (Agriculture \& Mining), the secondary sector (manufacturing and building \& construction) and the tertiary sector (services and commerce). Thus, the real sector is where goods and services are produced through the combined utilization of raw materials and other production factor such as labour, land and capital. It therefore forms the main driving force of any economy and the engine of economic growth and development.

Balance of payments on the other hand is a statistical statement that systematically summarizes, for a specific time period, the economic transactions of an economy with the rest of the world. Transactions, for the most part between residents and nonresidents, consist of those involving goods, services, and income; those involving financial claims on, and liabilities to, the rest of the world; and those classified as transfers.

\subsection{Theoretical Review}

Exchange rate deregulation is generally believed to increase economic growth and development. According to Thomson (2007), the financial liberalization theory of International Monetary Fund states that the more liberalization of financial system, the more growth in economic development. One aspect of financial liberalization is exchange rate management. The exchange rate management could be in form of fixed, floating pegged and deregulated or floating exchange rate system.

Some economists believe that in most circumstances floating exchange rates are preferable to fixed exchange rates because floating exchange rates automatically adjust to economic circumstances and allow a country to dampen the impact of shocks and foreign business cycles. This ultimately reduces the possibility of having a balance of payments crisis. However, pure floating exchange rates pose some threats because is not as stable as a fixed exchange rate. If a currency floats, there could be rapid appreciation or depreciation of value. This could harm the country's imports and exports. If the currency's value increases too drastically, the country's exports could become too costly which would harm the country's employment rates. On the other hand, if the currency's value decreases too drastically, the country may not be able to afford crucial imports. A country can obtain the benefits of a free floating system but still has the option to intervene and minimize the risks associated with a free floating currency by adopting pegged floating system. If a currency's value increases or decreases too rapidly, the central bank can intervene and minimize any harmful effects that might result from the radical fluctuation.

Never the less, flexible exchange rates serve to adjust the balance of trade. When a trade deficit occurs in an economy with a floating exchange rate, there will be increased demand for the foreign currency which will increase the price of the foreign currency in terms of the domestic currency. That in turn makes the price of foreign goods less attractive to the 
domestic market and decreases the trade deficit (Aliyu, 2011). However, Mahmood and Ali (2011) states that floating exchange rate induces uncertainty and risk in investment decision thereby affecting the national investment negatively, which have a destabilizing impact on the macroeconomic performance of a nation. Likewise the real sector of Nigerian economy has arguably been the engine of the country's economic transformations over the years, most importantly, the sector has metamorphosed into an emerging industrial that can hardly be ignored, but exchange rate fluctuation is believed to have hampered the real sector revolution (Adubi \& Okumadewa, 1999).

\subsection{Review of Related Literature}

Some related research works that have been carried out on similar topics are reviewed in order to ascertain other scholars view on the topic.

Ogun (2006) studied the effects of real exchange rate misalignment and volatility on the growth of non-oil exports. He employed the standard trade theory model of determinants of export growth and two different measures of real exchange rate misalignment, ie deviation of the purchasing power parity (PPP), and model based estimation of equilibrium real exchange rate (ERER). He observed that both real exchange misalignment and volatility adversely affected growth of Nigerian non-oil exports.

Ikpefan (2007) examine the effect of exchange rate deregulation on industrial produce in Nigerian economy using co-integration and error correction mechanism. The result showed that exchange rate had a significant effect on industrial out-put.

Adebiyi and Dauda (2009) studied the effect of trade liberalization policy on Industrialization growth performance in Nigeria using error correction model. They concluded that trade liberalization promoted growth in the Nigerian industrial sector and stabilized the exchange rate market between 1970 and 2006.

David, Umeh and Ameh (2010) also analyzed the effect of exchange rate fluctuations on Nigerian manufacturing industry applying multiple regression tools. The result revealed that there is a negative relationship between exchange rate volatility and manufacturing sector performance.

Eme and Johson (2012) evaluated the relationship between exchange rates and GDP growth in Nigeria from 1986 to 2010 using a simultaneous equations model and a generalized Method of Moments (GMM) technique. The results revealed that there is no evidence of a strong direct relationship between changes in exchange rate and output growth in Nigeria. They concluded that improvements in exchange rate management are necessary but not adequate to revive the Nigerian economy.

Asher (2012) examined the impact of exchange rate fluctuation on the Nigeria economic growth from $1980-2010$. The result showed that exchange rate fluctuation has a positive effect on the economic growth.

Obansa, Okoroafor, Aluko and Millicent (2013) also examined the relationship between exchange rate liberalization and economic growth in Nigeria from 1970-2010. The result indicated that exchange rate liberalization has a strong impact on economic growth and has 
also promoted economic growth in Nigeria.

Ochei, Akhanolu and Chibuzor (2015) studied the effect of deregulation of foreign exchange market on industrial produce in Nigeria using secondary data on industrial produce, exchange rate, inflation rate, labour force per time, capital stock and political regulations/instability. The data was analyzed using Ordinary Least Square Methods. The result showed that while both labour and capital are positively significant in explaining industrial produce, inflation was negatively significant in explaining it.

Tams-Alasia, Okoye \& Ejemegovwi (2018) studied the impact of exchange rate deregulation on manufacturing sectors performance in Nigeria from 1980-2016, using normalized co-integration technique and granger causality test. The result revealed that exchange rate deregulation has no significant positive long-run effect on manufacturing sector performance.

Orji, Ogbuabor \& Okeke (2018) studied the impact of exchange rate movement on the manufacturing sector in Nigeria over the period of 1981-206. The variables of study were exchange rate, manufacturing GDP, government capital expenditure, foreign direct investment, credit to private sector and value of imports. The result showed exchange rate movement has a positive relationship with manufacturing GDP, government capital expenditure, import and FDI, but it has negative relationship with credit to private sector.

Isibor, Olokoyo, Arogundade, Osuma \& Ndigwe (2019) analyzed the effect of exchange rate management on output performance of both the agricultural sector and the manufacturing sector in Nigeria from 1981 to 2015 using ordinary least square technique. The results showed that exchange rate management has positive and significant effect on agricultural sector only

\section{Methodology}

This is a comparative study that examined the pre and post exchange rate deregulation on selected Nigerian macro economic variables like balance of payment and real sector performance from 1960 to 2011, i.e. twenty five years before and twenty five years after deregulation in Nigeria. The study made use of only secondary data obtained from Nigerian statistical bulletin starting from 1960 to 1985 as pre deregulation period, and 1986 to 2011 as post deregulation period. The formulated hypotheses were tested using Paired Sample T test.

Model specification

The study adapted the model of Eme and Johson (2012) who studied the relationship between exchange rate and GDP growth in Nigeria. The model is stated as follows:

$$
\begin{gathered}
\ln Y r t=\beta 0+\beta 1 \ln M s t+\beta 2 \ln e x t+\beta 3 \ln e x t-1+\beta 4 \ln i n f t+\beta 5 \ln y r t-1+\varepsilon t \\
\ln i n f t=\alpha 0+\alpha 1 \ln M S t+\alpha 2 \ln Y r+\alpha 3 \inf t-1+\alpha 4 \text { ext }+\varepsilon t
\end{gathered}
$$

Where inf indicates inflation rate, MS is money supply (broadly defined); Yr is real output proxied by real GDP, and inft-1 is a proxy for expected inflation, while ex is exchange rate and $\varepsilon$ is the error term.

\section{The model for this research work is stated as follows}


Model one: $Y_{1}=\quad \beta_{0}+\beta_{1} \times 1+\mu_{t}$

Model two: $\mathrm{Y}_{2}=\gamma_{\mathrm{o}}+\gamma_{1} \times 1+\varepsilon_{\mathrm{t}}$

$=\mathrm{LNDER}_{\mathrm{t}}=\beta_{\mathrm{o}}+\left(\beta_{1} \mathrm{LNBOP}\right)+\mu_{\mathrm{t}}$

$=\mathrm{LNDER}_{\mathrm{t}}=\gamma_{\mathrm{o}}+\left(\gamma_{1} \mathrm{LNRGDP}\right)+\varepsilon_{\mathrm{t}}$.

Where LNDER; log Nigerian Deregulated Exchange Rate, LNRGDP indicates log Nigerian Real Gross Domestic Product and $L$ NBOP is $\log$ Nigerian Balance of Payment. $\mu_{t} \& \varepsilon_{t}$ are error terms and $\beta_{0}, \beta_{1,}, \gamma_{o} \& \gamma_{1}$ are Intercept of the model

\section{Data Presentation and Analysis}

The data for the variables of choice were presented in Tables 1 and 2.

Table 1. Pre-deregulation selected Nigerian Macro economic variables from1960-1985

\begin{tabular}{|c|c|c|c|}
\hline Year & $\begin{array}{l}\text { Balance of Payment } \\
\text { ( Million) }\end{array}$ & $\begin{array}{l}\text { Official Exchange Rate } \\
\text { (per 1 USD) }\end{array}$ & $\begin{array}{c}\text { Real Gross Domestic Product } \\
\text { ( Million) }\end{array}$ \\
\hline 1960 & 9.20 & 0.7143 & $2,489.00$ \\
\hline 1961 & 4.80 & 0.7143 & $2,501.20$ \\
\hline 1962 & -3.00 & 0.7143 & $2,597.60$ \\
\hline 1963 & -1.00 & 0.7143 & $2,825.60$ \\
\hline 1964 & 20.60 & 0.7143 & $2,947.60$ \\
\hline 1965 & -4.20 & 0.7143 & $3,146.80$ \\
\hline 1966 & 4.60 & 0.7143 & $3,044.80$ \\
\hline 1967 & 46.00 & 0.7143 & $2,527.30$ \\
\hline 1968 & 31.00 & 0.7143 & $2,543.80$ \\
\hline 1969 & 47.80 & 0.7143 & $3,225.50$ \\
\hline 1970 & 46.60 & 0.7143 & $4,219.00$ \\
\hline 1971 & 117.40 & 0.6955 & $4,715.50$ \\
\hline 1972 & 57.20 & 0.6579 & $4,892.80$ \\
\hline 1973 & 197.50 & 0.6579 & $5,310.00$ \\
\hline 1974 & $3,102.20$ & 0.6299 & $15,919.70$ \\
\hline 1975 & 157.50 & 0.6159 & $27,172.00$ \\
\hline 1976 & -339.00 & 0.6265 & $29,146.50$ \\
\hline 1977 & -527.20 & 0.6466 & $31,520.30$ \\
\hline 1978 & $-1,293.60$ & 0.6060 & $29,212.40$ \\
\hline 1979 & $1,868.90$ & 0.5957 & $29,948.00$ \\
\hline 1980 & $2,402.20$ & 0.5464 & $31,546.80$ \\
\hline 1981 & $-3,020.80$ & 0.6100 & $205,222.10$ \\
\hline 1982 & $-1,398.30$ & 0.6729 & $199,685.30$ \\
\hline
\end{tabular}




$\begin{array}{llll}1983 & -301.30 & 0.7241 & 185,598.10 \\ 1984 & 354.90 & 0.7649 & 183,563.00 \\ 1985 & -349.10 & 0.8938 & 201,036.30\end{array}$

Source: Central Bank of Nigeria statistical bulletin

Table 1 depicts the data of the selected Nigerian Macro economic variables before the exchange devaluation from 1960 to 1985. The selected variables are Nigerian Balance of Payment, Real Gross Domestic Period and Real exchange rate.

Table 2. Post deregulation selected Nigerian Macro economic variables from1960-2018

\begin{tabular}{|c|c|c|c|}
\hline Year & $\begin{array}{c}\text { Balance of Payment } \\
\text { ( Million) }\end{array}$ & $\begin{array}{l}\text { Official Exchange Rate } \\
\text { (per 1 USD) }\end{array}$ & $\begin{array}{c}\text { Real Gross Domestic Product } \\
\text { ( Million) }\end{array}$ \\
\hline 1986 & $-4,099.10$ & 1.75 & $15,237,990.00$ \\
\hline 1987 & $-17,964.80$ & 4.02 & $15,263,930.00$ \\
\hline 1988 & $-20,795.00$ & 4.54 & $16,215,370.00$ \\
\hline 1989 & $-22,993.50$ & 7.36 & $17,294,680.00$ \\
\hline 1990 & $-5,761.90$ & 8.04 & $19,305,630.00$ \\
\hline 1991 & $-15,796.60$ & 9.91 & $19,199,060.00$ \\
\hline 1992 & $-101,404.90$ & 17.30 & $19,620,190.00$ \\
\hline 1993 & $-41,736.80$ & 22.07 & $19,927,990.00$ \\
\hline 1994 & $-42,600.00$ & 21.99 & $19,979,120.00$ \\
\hline 1995 & $-195,200.00$ & 21.90 & $20,353,200.00$ \\
\hline 1996 & $-53,200.00$ & 21.88 & $21,177,920.00$ \\
\hline 1997 & $1,100.00$ & 21.89 & $21,789,100.00$ \\
\hline 1998 & $-220,700.00$ & 21.89 & $22,332,870.00$ \\
\hline 1999 & $-326,600.00$ & 92.34 & $22,449,410.00$ \\
\hline 2000 & $314,100.00$ & 101.70 & $23,688,280.00$ \\
\hline 2001 & $24,700.00$ & 111.23 & $25,267,540.00$ \\
\hline 2002 & $-563,500.00$ & 120.58 & $28,957,710.00$ \\
\hline 2003 & $-162,300.00$ & 129.22 & $31,709,450.00$ \\
\hline 2004 & $1,124,200.00$ & 132.89 & $35,020,550.00$ \\
\hline 2005 & $-2,394,900.00$ & 131.27 & $37,474,950.00$ \\
\hline 2006 & $-2,206,500.00$ & 128.65 & $39,995,500.00$ \\
\hline 2007 & $-1,811,800.00$ & 125.81 & $42,922,410.00$ \\
\hline 2008 & $-2,463,400.00$ & 118.55 & $46,012,520.00$ \\
\hline 2009 & $-3,927,500.00$ & 148.90 & $49,856,100.00$ \\
\hline 2010 & $-2,276,200.00$ & 150.30 & $54,612,260.00$ \\
\hline 2011 & $-810,100.00$ & 153.86 & $57,511,040.00$ \\
\hline
\end{tabular}


2012

2013

$-787,300.00$

157.50

157.31

158.55

2014

$-2,074,800.00$

2016

2017

2018
192.44

253.49

$3,235,500.00$

305.79

305.08
$59,929,890.00$

$63,218,720.00$

$67,152,790.00$

$69,023,930.00$

$67,931,230.00$

$68,490,980.00$

$69,810,020.00$

Source: Central Bank of Nigeria statistical bulletin

Table 2 depicts the data of the selected Nigerian Macro economic variables after the exchange devaluation starting from 1986 to 2018, though the analysis was twenty five years before and twenty five years after. The selected variables are Nigerian Balance of Payment, Real Gross Domestic Period and Real exchange rate.

\subsection{Test of Hypotheses One}

The formulated hypothesis one is re-stated as follows

Ho: Deregulated exchange rate has no significant relationship with Nigerian Balance of Payment

Hi: De-regulated exchange rate has significant relationship with Nigerian Balance of Payment

\section{Balance of Payment}

Table 3. Descriptive Properties of BOP before and after De-Regulation

\begin{tabular}{cccccc}
\hline Year & $\mathrm{N}$ & Minimum & Maximum & Mean & Std. Deviation \\
\hline BOP @ t & 26 & 0.55 & 0.89 & 0.6847 & 0.06766 \\
BOP @ t-1 & 33 & 1.75 & 305.79 & 101.8182 & 85.90233 \\
Valid N (listwise) & 26 & & & & \\
\hline
\end{tabular}

Source: SPSS Version 21 output data

Note: $(\mathrm{t})$ represents periods before de-regulation and $(\mathrm{t}+1)$ reflects periods of de-regulation

Table 4. Paired Samples Test of BOP before and after De-Regulation

\begin{tabular}{|c|c|c|c|c|c|c|c|c|}
\hline & \multicolumn{5}{|c|}{ Paired Differences } & \multirow{3}{*}{$\mathrm{T}$} & \multirow{3}{*}{ df } & \multirow{3}{*}{$\begin{array}{l}\text { Sig.(2-ta } \\
\text { iled) }\end{array}$} \\
\hline & \multirow{2}{*}{ Mean } & \multirow{2}{*}{$\begin{array}{c}\text { Std. } \\
\text { Deviation }\end{array}$} & \multirow{2}{*}{$\begin{array}{l}\text { Std. Error } \\
\text { Mean }\end{array}$} & \multicolumn{2}{|c|}{$\begin{array}{c}95 \% \text { Confidence Interval of } \\
\text { the Difference }\end{array}$} & & & \\
\hline & & & & Lower & Upper & & & \\
\hline $\begin{array}{c}\text { Pair } 1 \text { BOP@ (t) } \\
\text { BOP@(t+1) }\end{array}$ & -69.69380 & 58.97421 & 11.56579 & -93.51400 & -45.87360 & -6.026 & 25 & .000 \\
\hline
\end{tabular}

Source: SPSS Version 21 output data

Note: $(\mathrm{t})$ represents periods before de-regulation and $(\mathrm{t}+1)$ reflects periods of de-regulation 


\section{Macrothink}

Table 3 provides insight to the descriptive properties of balance of payment position before and after de-regulation. It was evidence in that the mean of balance of payment before de-regulation is 0.89 , while after de-regulation is 101.82 . The standard deviation of balance of payment after de-regulation (0.067) is better than post de-regulation (85.9). Judging by the standard deviation, Nigeria witnessed a less deficit in her balance of payment position before de-regulation when compared to post de-regulation. With regard to the difference in the mean of balance of payment in pre and post de-regulation, the p-value of the paired T-Test in Table 4 is significant at 5\% level of significance. By implication, there is a significance difference in balance of payment position of Nigeria before and after de-regulations. With this, it can be adduced that the significant difference in the mean of balance of payment in pre and post de-regulation would be attributable to exchange rate de-regulation which started in 1986.

\subsection{Test of Hypotheses Two}

The formulated hypothesis two is re-stated as follows

Ho: De-regulated exchange rate has not significantly influenced Nigerian Real sector productivity.

Hi: De-regulated exchange rate has significantly influenced Nigerian Real sector productivity.

Table 5. Descriptive Properties of BOP before and after De-Regulation

\begin{tabular}{cccccc}
\hline Year & N & Minimum & Maximum & Mean & Std. Deviation \\
\hline RGDP @ t & 26 & 2489.00 & 205222.10 & 46790.6538 & 74665.97163 \\
RGDP @ t-1 & 33 & 15237990.00 & 69810020.00 & 36628252.4242 & 19418575.03764 \\
Valid N (listwise) & 26 & & & & \\
\hline
\end{tabular}

Source: SPSS Version 21 output data

Note: $(t)$ represents periods before de-regulation and $(t+1)$ reflects periods of de-regulation

Table 6. Paired Samples Test of RGDP before and after De-Regulation

\begin{tabular}{|c|c|c|c|c|c|c|c|c|}
\hline & \multicolumn{5}{|c|}{ Paired Differences } & \multirow{3}{*}{$\mathrm{T}$} & \multirow{3}{*}{ Df } & \multirow{3}{*}{$\begin{array}{l}\text { Sig.(2-ta } \\
\text { iled) }\end{array}$} \\
\hline & \multirow[t]{2}{*}{ Mean } & \multirow[t]{2}{*}{ Std. Deviation } & \multirow{2}{*}{$\begin{array}{l}\text { Std. Error } \\
\text { Mean }\end{array}$} & \multicolumn{2}{|c|}{$\begin{array}{c}95 \% \text { Confidence Interval of the } \\
\text { Difference }\end{array}$} & & & \\
\hline & & & & Lower & Upper & & & \\
\hline $\begin{array}{c}\text { Pair } 1 \text { RGDP@(t) } \\
\text { RGDP@(t+1) }\end{array}$ & -28536854.3 & 12671418.9 & 2485069.7 & -33654951.2 & -23418757.5 & -11.48 & 25 & .000 \\
\hline
\end{tabular}

Source: SPSS Version 21 output data

Note: $(t)$ represents periods before de-regulation and $(t+1)$ reflects periods of de-regulation 
The descriptive properties of real gross domestic product in Table 5 show a pre and post de-regulation mean of 46,790.65 and 36,628,252.42 with standard deviation of 74,665.97 and $19,418,575.04$ respectively. The standard deviation of the pre de-regulation is better than the post de-regulation, while the post de-regulation mean is higher than pre de-regulation. The p-value of the mean of real gross domestic product of Nigeria before and after de-regulation is significant at $5 \%$ as reveal by the paired sample T-test in Table 6 . This is to say that there is a significant difference in Nigeria's real sector productivity before and after deregulation. Consequently, it will not be wrong to assert that the significant difference in real sector productivity before and after de-regulation was as a result of the 1986 de-regulation of exchange rate. That is, the growth in real sector productivity from 1986 to 2018 was significantly attributed to deregulation of exchange rate.

\section{Summary, Conclusion and Recommendation}

From the result of the analysis, it can be ascertained that there is a significant difference in Nigerian Balance of Payment and Real Sector Productivity before and after the exchange rate deregulation. While the deregulation has a negative influence on Nigerian balance of payment, it has a positive influence on the Real Sector Productivity proxied by Real Gross Domestic Product.

It is evident that the deterioration in Nigerians balance of payment from 1986 to 2018 was on increase compared with the level balance of payment deficit witnessed from 1960 to 1985. This is an indication that deregulation of exchange rate did not increase the Nigerian general export, but oil export only, which is also an indication that Nigerian domestic industries did not contribute significantly to the country's export, else their export could have reflected in the country' balance of payment.

To minimize the adverse effect of exchange rate deregulation, the monetary authority can consider placing a crawling peg (minimum level of depreciation) on Naira exchange rate levels, that will reduce the domestic's industries cost of production because most of these industries make use of imported raw materials and machineries. Again, export abilities of these industries can be enhanced by granting them export incentives such as export subsidies inform of free standard packaging and external credit guarantee.

\section{References}

Adebayo O. O. (2013). Understanding Monetary Policy; the real sector. Central Bank of Nigeria Series 33

Adebiyi, M. A., \& Dauda, R. O. S. (2009). Trade liberalization policy and industrialization growth performance in Nigeria: An Error Correction Mechanism Technique. Central Bank of Nigeria 45th annual conference Abuja.

Adubi, A. A., \& Okumadewa, F. (1999) Price exchange rate volatility and Nigerian's trade flows: A dynamic analysis of Nairobi. African Economic Research Consortium research paper 87.

Aliyu, S. R. U. (2011). Impact of oil price shock and exchange rate volatility on economic 
growth in Nigeria: An Empirical Investigation. Research Journal of International Studies.

Arize, A. C., Osang, T., \& Slottje, D. J. (2000). Exchange rate volatility and foreign trade: Evidence from thirteen LDCs. Journal of Business and Economic Statistics, 18(1), 10-17.

Asher O. J. (2012). The Impact of exchange rate fluctuation on the Nigeria economic growth (1980 - 2010). Unpublished B.sc Thesis of Caritas University Emene, Enugu State, Nigeria.

Auboin, M., \& Ruta, M. (2011). The relationship between exchange rates and international trade: A review of economic literature' World Trade Organization (WTO).

David, Umeh, \& Ameh. (2010). Effect of exchange rate fluctuations on Nigeria manufacturing sector. African Journal of Business Management, 4(14), 2994-2998.

Eichengreen, B., \& Leblang, D. (2003). Exchange rates and cohesion: Historical perspectives and political-economy considerations. Journal of Common Market Studies, 41, 797-822.

Eme, O. A., \& Johnson, A. A. (2012). Effect of exchange rate movements on economic growth in Nigeria. CBN Journal of Applied Statistics, 2(2), 1-28.

Ibenta, S. N. O. (2014). International trade and finance. Lagos: African Basic Economy Limited.

Ikpefan, O. (2007) Deregulation of foreign exchange market and the effect on industrial produce in Nigeria. Journal of Chartered Institute of Stock Brokers.

Isibor, A., Olokoyo, F., Arogundade, M., Osuma, G., \& Ndigwe, C. (2019) Exchange rate management and sectoral output performance in Nigeria. International Journal of Supply Chain Management, 129-134.

Lumen boundless-economics, Exchange rates. Retrieved from https://courses.lumenlearning.com/boundless-economics/chapter/exchange-rates/

Mahmood, I., \& Ali, S. Z. (2011). Impact of exchange rate volatility on macroeconomic performance of Pakistan. International Research Journal of Finance and Economics, 64, $1450-2887$.

Obansa, S. A. J., Okoroafor, O. K. D., Aluko, O. O., \& Millicent, E. (2013) Perceived relationship between exchange rate, interest rate and economic growth in Nigeria: 19702010. American Journal of Humanities and Social Sciences, 1(3), 116-124.

Ochei, I., Akhanolu, I. A., \& Chibuzor, O. T. (2015). Deregulation of foreign exchange market on industrial produce in Nigeria. Journal of chartered Institute of Stock Broker, 8(3), 3-18

Ogun, O. (2006). Real exchange rate behaviour and Non-oil export growth in Nigeria. African Journal of Economic Policy, 11(1).

Orji, A., Ogbuabor, J. E. \& Okeke, C. (2018). Impact of exchange rate movements on the manufacturing sector in Nigeria. Journal of infrastructure development, 10, 1-2. 
Servén, L. (2003). Real-exchange rate uncertainty and private investment in LDCs. Review of Economics and Statistics, 85, 212-218.

Tams-Alasia, O., Olokoyo, F., Okoye, L., \& Ejemeyovwi, J. (2018). Impact of exchange rate deregulation on manufacturing sector performance. International Journal of Environment, Agriculture and Biotechnology, 3(3), 994-1001.

Thomson, G. S. (2007). A Taxonomy of Selected Finance Theories; Theory of International. $\begin{array}{llll}\text { Electronic Journal, } 23 . & \text { Retrieved }\end{array}$ https://www.researchgate.net/publication/228293377

\section{Copyright Disclaimer}

Copyright for this article is retained by the author(s), with first publication rights granted to the journal.

This is an open-access article distributed under the terms and conditions of the Creative Commons Attribution license (http://creativecommons.org/licenses/by/3.0/). 